\title{
Delaware Language
}

National Cancer Institute

\section{Source}

National Cancer Institute. Delaware Language. NCI Thesaurus. Code C153896.

An Eastern Algonquian language spoken by the native Lenape people of the New York City area. 